\title{
Specific Treatment Exists for SARS-CoV-2 ARDS
}

\author{
Badar Kanwar ${ }^{1}$, Chul Joong Lee ${ }^{2} \mathbb{D}$ and Jong-Hoon Lee ${ }^{3, *}(\mathbb{D}$ \\ 1 Department of Pulmonary Critical Care Medicine, Hunt Regional Hospital, Greenville, TX 75401, USA; \\ Bkanwar2@yahoo.com \\ 2 Zein Pain Clinic Seongbuk, Seoul 02830, Korea; cjlee.mdphd@gmail.com \\ 3 Science \& Research Center, Seoul National University College of Medicine, Seoul 03080, Korea \\ * Correspondence: science@research.re.kr; Tel.: +82-2-762-3062; Fax: +82-2-762-3061
}

check for

updates

Citation: Kanwar, B.; Lee, C.J.; Lee, J.-H. Specific Treatment Exists for SARS-CoV-2 ARDS. Vaccines 2021, 9 , 635. https://doi.org/10.3390/ vaccines 9060635

Academic Editor: Giovanni Ferrara

Received: 17 May 2021

Accepted: 7 June 2021

Published: 10 June 2021

Publisher's Note: MDPI stays neutral with regard to jurisdictional claims in published maps and institutional affiliations.

Copyright: (C) 2021 by the authors. Licensee MDPI, Basel, Switzerland. This article is an open access article distributed under the terms and conditions of the Creative Commons Attribution (CC BY) license (https:/ / creativecommons.org/licenses/by/ $4.0 /)$.

\begin{abstract}
The COVID-19 pandemic, caused by severe acute respiratory syndrome coronavirus 2 (SARS-CoV-2), seems to be difficult to overcome. A pandemic of such a scale has not been seen since the 1918 influenza pandemic. Although the predominant clinical presentation is respiratory disease, neurological manifestations and sequelae are increasingly being recognized. We observed a case series of rapid recovery of ARDS within $24 \mathrm{~h}$ in the preliminary clinical features of COVID-19 ARDSassociated neurological disease. It was also noted that by 15 April, 2021, there was no SARS-CoV-2 ARDS on Sorok Island in South Korea, where lepers had been living together. We compared each of dapsone's effects on humans and considered those of SARS-CoV-2. Dapsone showed different effects in the brain. The Sorokdo National Hospital reported a relationship between dapsone and the neuroinflammasome of Alzheimer's disease (AD) in Sorok Island from January 2005 to June 2020. $\mathrm{AD}$ prevalence was low in the leprosy patient group who took dapsone regularly. The preliminary cross-sectional study of the trial group ( 22 subjects) and the control group ( 22 subjects) in the Hunt Regional Hospital reported the following results: The chi-square statistic is 5.1836 . The p-value is 0.022801 . The result is considered significant at $p<0.05$. The results from the medical treatment from 21 December to 29 December 2020 were considered. The mortality rates at the ARDS onset stage were $0 \%$ with dapsone administered as a standard COVID-19 treatment and 40\% without dapsone administered as a standard COVID-19 treatment, respectively. Based on the respiratory failure and sudden high death rate originating from the involvement of the brainstem, especially the pre-Bötzinger complex, dapsone can be used to significantly reduce the incidence of the cases of acute respiratory distress syndrome and other illnesses caused by SARS-CoV-2.
\end{abstract}

Keywords: brainstem; inflammasome; oral DNA vaccine

\section{Introduction}

In December 2019, there was a local outbreak of pneumonia of unknown cause in Wuhan (Hubei, China). This precipitated the COVID-19 pandemic, caused by the novel coronavirus severe acute respiratory syndrome coronavirus 2 (SARS-CoV-2), which has resulted in more than 145,289,885 confirmed cases globally and more than 3,083,440 deaths [1,2]. Established public health measures for the control of SARS-CoV-2 continue to rely on social distancing; frequent hand washing; face coverings; and practical test, trace, and isolate systems [3].

The COVID-19 pandemic has led to the reconsideration of public health policies, healthcare providers, and the virus' effects on the central nervous system. During the period of the pandemic, only one researcher found a way to treat the large number of patients who suffered from neuroinflammation or neuroinflammasome as a result of SARS-CoV-2 [4-6]. He explained that the respiratory failure and sudden high death rate in COVID-19 acute respiratory distress syndrome (ARDS) patients originated from the involvement of the brainstem, especially the pre-Bötzinger complex $[7,8]$. His team used dapsone in COVID-19 ARDS patients to compete with SARS-CoV-2 inflammasomes. 


\section{Evidence from Brain Diseases}

A study on the elderly diagnosed with mild cognitive impairment (MCI) from 2008 to 3 January 2021 was designed to classify MCI and Alzheimer's disease (AD) cases as dementia syndrome with(out) cognitive impairment (Figure 1).

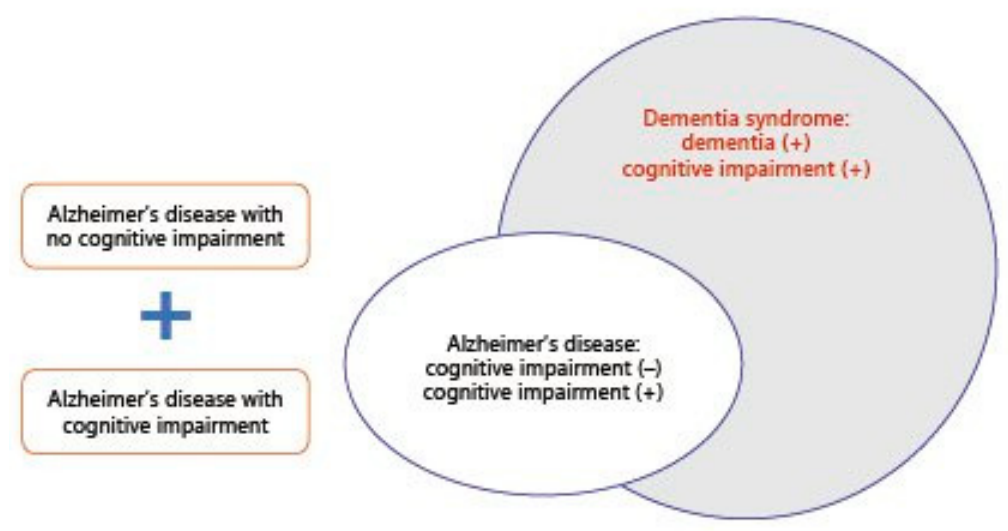

Figure 1. Scope of Alzheimer's disease and dementia syndrome [9].

And it pondered once more the Japanese null hypothesis for dapsone's therapeutic potential for AD [10-12] (Figure 2).

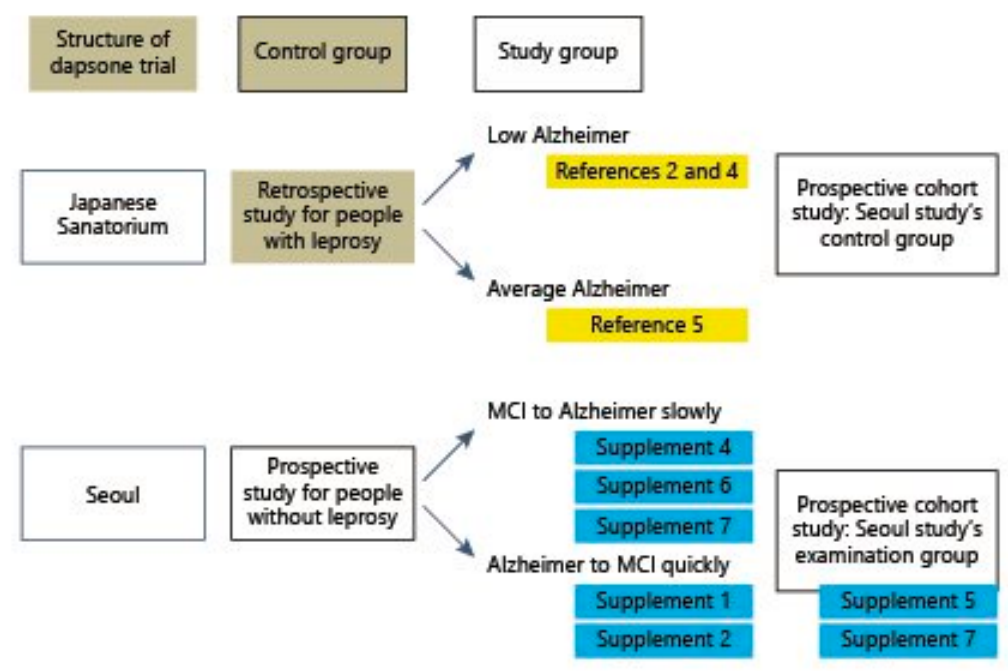

Figure 2. Structure and result of prospective cohort.

The $\mathrm{AD}$ patients recovered to $\mathrm{MCI}$ states, and their quality of daily life was improved, with the use of dapsone $[9,13]$.

The authors of this study also created and expanded the Seoul cohort based on the thesis that dapsone's sulfone group would protect cerebrovascular blood vessels through the action of the sulfone amide group of dapsone, and they conducted research on $\mathrm{AD}$ and Parkinson's disease (PD) patients [9]. In December 2020, the study confirmed that its therapeutic mechanism was as a neuroinflammasome competitor $[6,13,14]$.

Before dapsone was identified as an inflammasome competitor, clinicians used it as an adjuvant [15], alternative [16], augmentation [17,18], or active ingredient [19,20]. Dapsone has been used as a therapeutic agent for mild cognitive impairment [9,21], AD [14], PD [22,23], seizures [24], strokes [13,25,26], and finally, COVID-19 ARDS [6,27]. 


\section{Projected Neurological Findings for COVID-19-Associated ARDS}

He suggested that dapsone might be a treatment for SARS-CoV-2 in January 2020 because of the clinical manifestations of SARS-CoV-2 and dapsone's effects in humans. He compared each of dapsone's effects on humans and considered those of SARS-CoV-2 [6]. However, dapsone showed different effects in the brain (Table 1).

Table 1. The different neurological manifestations of SARS-CoV-2's and dapsone's effects in humans.

\begin{tabular}{|c|c|c|c|}
\hline Clinical Manifestations & SARS-CoV-2 Symptoms & Dapsone's Effects & \\
\hline $\begin{array}{l}\text { Hypersensitivity } \\
\text { reactions }\end{array}$ & $\begin{array}{l}\text { SARS-CoV-2 symptoms are like a severe } \\
\text { idiosyncratic reaction to dapsone } \\
\text { characterized by the clinical triad of fever, } \\
\text { rash, and systemic involvement, which can } \\
\text { cause powerful organ (heart, kidney, lung, } \\
\text { and brain) dysfunction [28] }\end{array}$ & $\begin{array}{l}\text { The syndrome is a severe idiosyncratic } \\
\text { reaction to dapsone characterized by the } \\
\text { clinical triad of fever, rash, and systemic } \\
\text { involvement (most commonly of the liver } \\
\text { and the hematologic system), which can } \\
\text { cause severe organ dysfunction [29] }\end{array}$ & Similar \\
\hline Hematology laboratory & $\begin{array}{c}\text { Focal fibrin clusters mixed with } \\
\text { mononuclear inflammatory cells, decreased } \\
\text { eosinophils, decreased lymphocytes, } \\
\text { increased neutrophils [30], lymphopenia, } \\
\text { leukocytosis, neutrophilia, and } \\
\text { thrombocytopenia [31] }\end{array}$ & $\begin{array}{l}\text { Leukocytosis and eosinophilia [32], } \\
\text { resembling a mononucleosis infection [33] }\end{array}$ & Similar \\
\hline Anemia & $\begin{array}{l}\text { Thrombocytopenia and consumptive } \\
\text { coagulopathy [31] }\end{array}$ & $\begin{array}{l}\text { Hemolytic anemia and } \\
\text { methemoglobinemia [34] }\end{array}$ & Similar \\
\hline $\begin{array}{c}\text { Liver disease, } \\
\text { pancreatic disease }\end{array}$ & $\begin{array}{c}\text { Clinically significant liver injury is } \\
\text { uncommon [35]; pancreatic cells highly } \\
\text { express ACE2 [36] }\end{array}$ & $\begin{array}{c}\text { Hepatitis/liver toxicity [33]; cholangitis, } \\
\text { colitis, and thyroiditis [37]; pancreatitis and } \\
\text { pleural effusion [38] }\end{array}$ & Similar \\
\hline Renal disease & $\begin{array}{c}\text { Severe collapsing, focal segmental } \\
\text { glomerulosclerosis, and acute } \\
\text { tubular necrosis [39] }\end{array}$ & Acute renal failure [33] & Similar \\
\hline Cardiac disease & $\begin{array}{c}\text { Acute myocardial injury and chronic } \\
\text { damage to the cardiovascular system [40] }\end{array}$ & $\begin{array}{c}\text { Myocarditis, and dapsone-induced } \\
\text { hypersensitivity syndrome-associated } \\
\text { complete atrioventricular block [37]; } \\
\text { myocardial injury [41] }\end{array}$ & Similar \\
\hline Pulmonary disease & $\begin{array}{l}\text { Coronavirus disease (COVID-19)-related } \\
\text { pneumonia }[28,40]\end{array}$ & $\begin{array}{l}\text { Pneumonitis [37]; pneumonia or multiple } \\
\text { organ failure [41] }\end{array}$ & Similar \\
\hline Neurologic disease & $\begin{array}{l}\text { Large-vessel stroke [42] encephalopathy, } \\
\text { prominent agitation and confusion, and } \\
\text { corticospinal tract signs }[43,44]\end{array}$ & $\begin{array}{c}\text { Recovery of dementia syndrome following } \\
\text { treatment of brain inflammation [45]; } \\
\text { dapsone alleviated MCI, early AD, } \\
\text { and stroke [13] }\end{array}$ & Different \\
\hline
\end{tabular}

South Korea has suffered severely from SARS-CoV (2002), influenza A virus subtype H1N1 (2009), MERS (2015), and SARS-CoV-2 (2020), and has reported the recurrence of leprosy according to regular medical examinations and diagnosis. The annual recurrence rate for leprosy has been below $0.02(\%)$ for the past ten years. The Korea Centers for Disease Control and Prevention (KCDC) are supplying dapsone to leprosy patients. The Sorokdo National Hospital is responsible for the treatment of respiratory infectious diseases and has reported no prevalence of each pandemic of SARS-CoV (2002), influenza A virus subtype H1N1 (2009), MERS (2015), or SARS-CoV-2 (2020) [6]. The Sorokdo National Hospital reported a relationship between dapsone and AD in Sorok Island from January 2005 to June 2020. AD prevalence is low in the leprosy patient group who took dapsone regularly (Table 2) (Figure 3). 
Table 2. AD prevalence (+/-) in the dapsone prescription (+)/non-prescription (-) group.

\begin{tabular}{ccccccccc}
\hline Year & $\begin{array}{c}\text { Dapsone } \\
(+)\end{array}$ & $\begin{array}{c}\text { Dapsone } \\
(-)\end{array}$ & $\begin{array}{c}\text { AD (+) } \\
\text { Total }\end{array}$ & $\begin{array}{c}\text { Dapsone } \\
(+)\end{array}$ & $\begin{array}{c}\text { Dapsone } \\
(-)\end{array}$ & $\begin{array}{c}\text { AD (-) } \\
\text { Total }\end{array}$ & $\begin{array}{c}\text { Dapsone } \\
(+) / A D(+)\end{array}$ & $\begin{array}{c}\text { Dapsone } \\
(+) / A D(-)\end{array}$ \\
\hline 2005 & 18 & 19 & 37 & 290 & 417 & 707 & 0.4865 & 0.4102 \\
2006 & 20 & 37 & 57 & 302 & 363 & 665 & 0.3509 & 0.4541 \\
2007 & 22 & 51 & 73 & 317 & 332 & 649 & 0.3014 & 0.4884 \\
2008 & 22 & 58 & 80 & 310 & 312 & 622 & 0.2750 & 0.4984 \\
2009 & 19 & 66 & 85 & 300 & 283 & 583 & 0.2235 & 0.5146 \\
2010 & 25 & 82 & 107 & 270 & 286 & 556 & 0.2336 & 0.4856 \\
2011 & 35 & 98 & 133 & 255 & 268 & 523 & 0.2632 & 0.4876 \\
2012 & 39 & 135 & 174 & 238 & 241 & 479 & 0.2241 & 0.4969 \\
2013 & 34 & 172 & 206 & 195 & 248 & 443 & 0.1650 & 0.4402 \\
2014 & 25 & 190 & 215 & 172 & 236 & 408 & 0.1163 & 0.4216 \\
2015 & 26 & 242 & 268 & 167 & 168 & 335 & 0.0970 & 0.4985 \\
2016 & 33 & 255 & 288 & 154 & 149 & 303 & 0.1146 & 0.5083 \\
2017 & 37 & 268 & 305 & 143 & 115 & 258 & 0.1213 & 0.5543 \\
2018 & 45 & 292 & 337 & 132 & 87 & 219 & 0.1335 & 0.6027 \\
2019 & 46 & 334 & 380 & 114 & 40 & 154 & 0.1211 & 0.7403 \\
2020 & 32 & 352 & 384 & 109 & 4 & 113 & 0.0833 \\
\hline
\end{tabular}

Independent $t$-test (two-tailed): the $t$-value is -7.41861 ; the $p$-value is $<0.00001$; the result is considered significant at $p<0.05$. Dependent $t$-test (two-tailed): the value of $t$ is 6.079808; the value of $p$ is 0.00002; the result is significant at $p<0.05$ (Supplementary Materials Section 1).

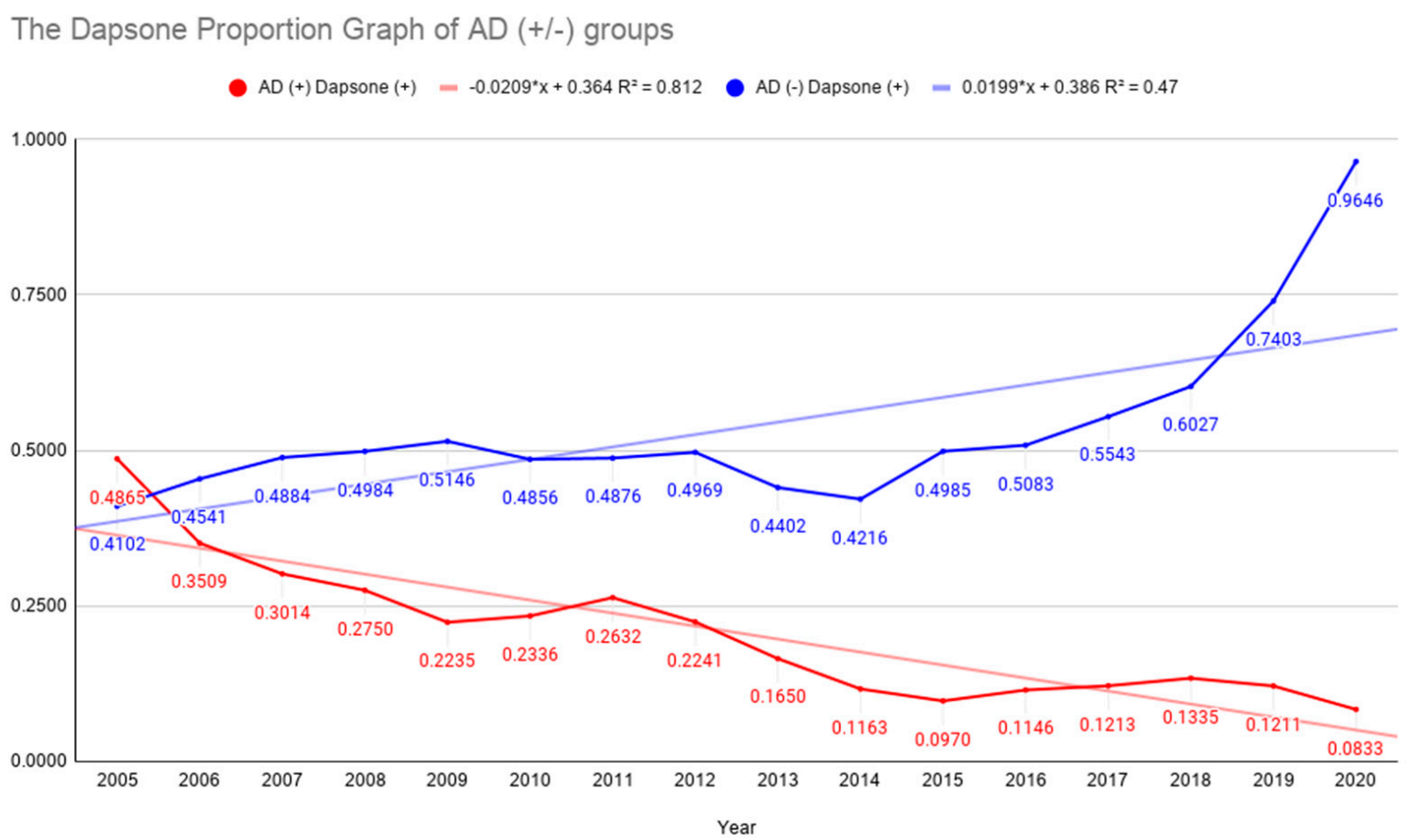

Figure 3. Dapsone proportion graph with(out) Alzheimer's disease groups. This study was conducted from 2005 to 2020 based on the medical records of the Sorokdo National Hospital that was established in May 1916 to treat leprosy [9]. However, the patient research in the report was initiated by Sister Marianne Stoeger and Sister Margaritha Pissarek, who moved to Sorok Island in February 1962 and October 1967, respectively. They left Sorok Island on 21 November 2005, returning to their homelands. The leprosy patients here have taken dapsone all their lives. The AD prevalence rate was very low in the leprosy patient group who took dapsone regularly.

CNS diseases are caused by inflammation and oxidative stress. The efficiency with which drugs acting on the CNS traverse the blood-brain barrier (BBB) is important [45]. Dapsone appears to have more significant anti-inflammatory effects due to its effective accumulation in the CSF in humans [46]. Dapsone's action as a neuroinflammasome competitor $[6,13]$ can be conjectured by comparing the AD prevalence in leprosy patients 
who have taken dapsone with that in those who have not [14]. Dapsone was deemed a neuroinflammasome competitor in conclusion.

In accordance with the Information Disclosure Act, the National Sorokdo Hospital responded as follows in the response form to the request for information disclosure on 15 April 2021-7767726:

"Regarding the "COVID-19 infection status among Hansen people of Sorokdo National Hospital" requested by the claimant, we will respond as follows: We are pleased to inform you that there are no patients infected with COVID-19 among Hansen Disease patients at National Sorokdo Hospital".

\section{The Preliminary Clinical Features of Neurological Disease Associated with COVID-19 ARDS}

Dr. B.K. insisted on using dapsone for ARDS patients as an inflammasome competitor at a COVID-19 committee at the Hunt Regional Medical Center in the U.S. The committee accepted the off-label use of dapsone with written informed consent after explaining its side effects and monitored its clinical results in terms of cytokine downregulation [47].

Dapsone treatment was commenced in a COVID-19 patient with progressively worsening hypoxia at the request of the family. Dapsone resulted in unexpectedly rapid clinical improvement within 24 h (Supplementary Materials Section 2; Case Reports, Case 3) (Table 3).

Table 3. $\mathrm{O}_{2}$ saturation graph (Supplementary Materials Section 2, Case 3).

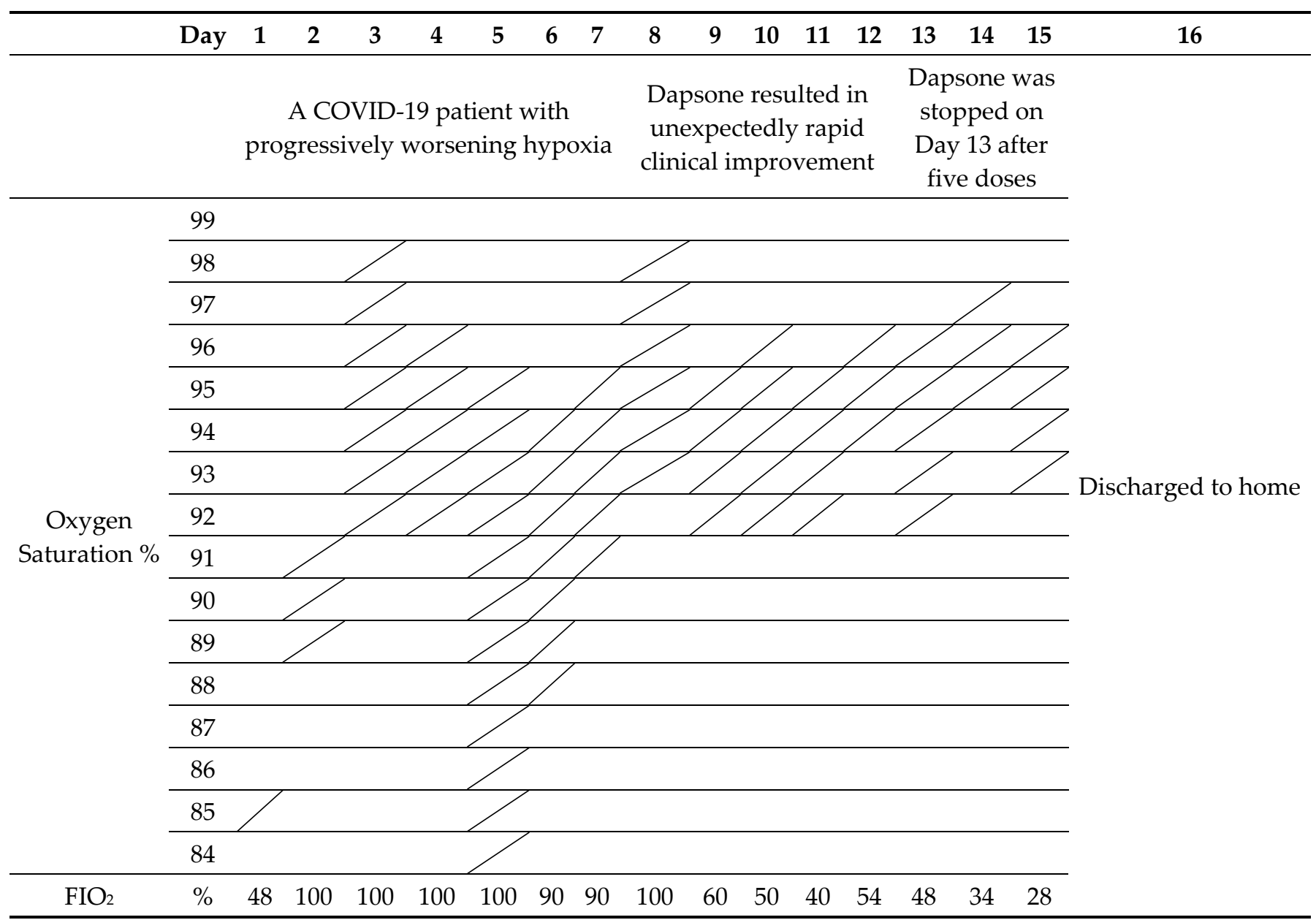


We used dapsone in 43 patients: 19 patients in the first period, 22 in the second period, and 2 (Dr. B.K.'s family) in the third period. We established objective criteria for improvement, including a reduction in $\mathrm{FIO}_{2}$ requirement and decrease in the progression of hypoxia. ARDS onset cases were based on $\mathrm{FIO}_{2}$ needs via simple nasal cannulation of up to $15 \mathrm{~L} / \mathrm{min}$. The criteria for aggravated cases were $\mathrm{FIO}_{2}$ administered via an $\mathrm{HFNC}$ (high-flow nasal cannula) of $95-100 \%$ or BiPAP (bilevel positive airway pressure). The criteria for severe cases of ARDS was the need for mechanical ventilation.

In the Hunt Regional Hospital intensive care unit (ICU), the medical staff in charge of COVID-19 patients changed approximately every eight days. The COVID-19 committee at the Hunt Regional Medical Center re-evaluated the results for two weeks after the firstperiod trial. Dr B.K. was ordered to stop prescribing dapsone. Following the committee's evaluation, dapsone was deemed appropriate for the treatment of ICU patients.

The case-control in the ICU was symmetrical (22/22) (Figure 4). The results from the medical treatment from 21 December to 29 December 2020 were statistically analyzed. When decreased $\mathrm{FIO}_{2}$ and no further progression of hypoxia were used as criteria for the effectiveness of dapsone, the results were statistically significant according to Fisher's exact test, and the chi-square test (Supplementary Materials Section 3).

Flow diagram 1.

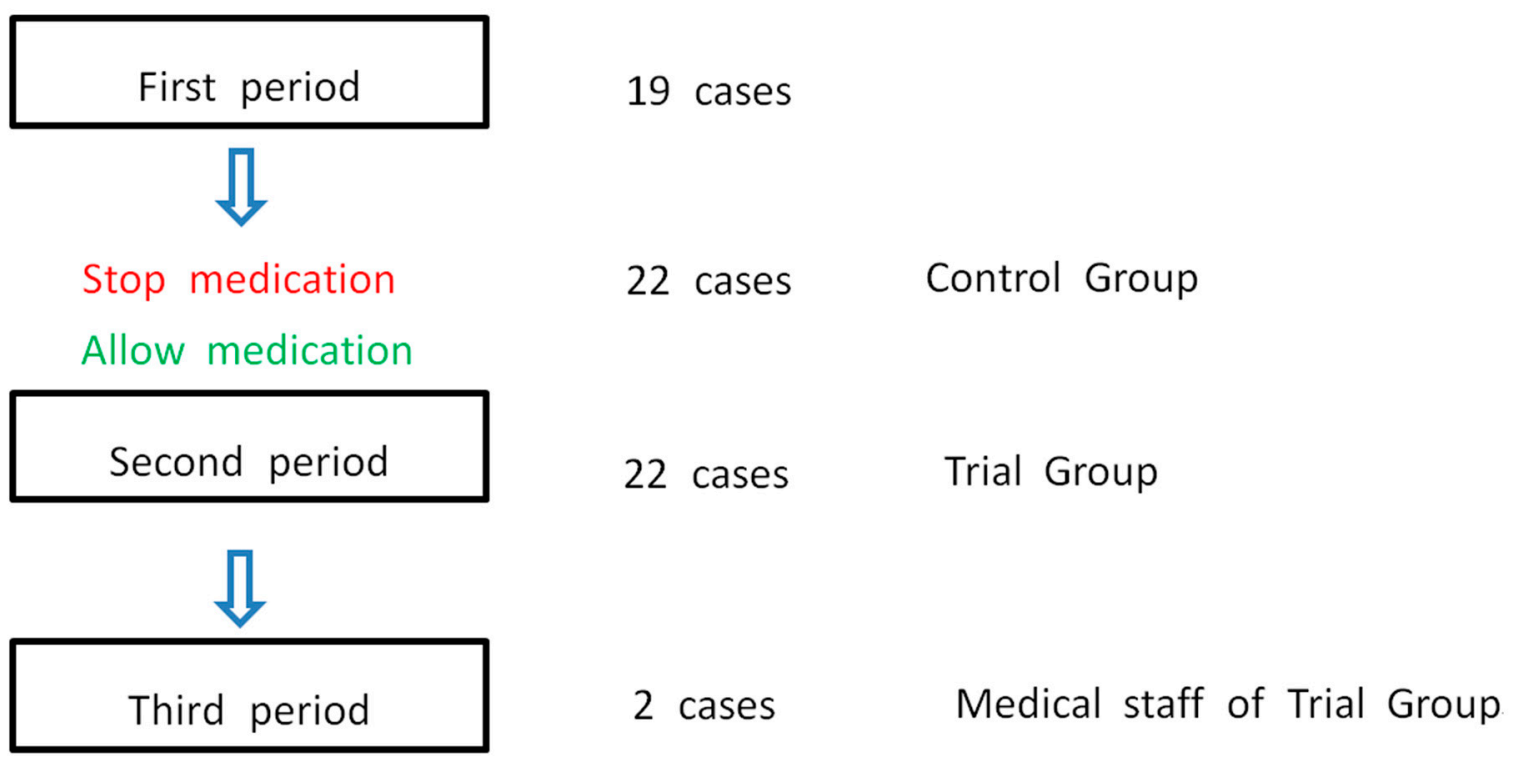

Figure 4. Flow diagram for cross-sectional study. An off-label medication was administered in 19 cases, and a control group (22 cases) and a trial group (22 cases) were observed [14].

\subsection{Statistics 1: Chi-Square Statistics}

The comparison was made assuming that only the decreased $\mathrm{FIO}_{2}$ was influential in the entire dapsone $(+)$ group and dapsone $(-)$ group, which applied to only the ARDS onset stage (Table 4).

Table 4. Chi-squared test.

\begin{tabular}{cccc}
\hline Study $\mathbf{3}$ & Decreased $\mathbf{F I O}_{\mathbf{2}}$ & Others & Row Totals \\
\hline Dapsone $(+)$ onset & $7(4.29)(1.72)$ & $1(3.71)(1.98)$ & 8 \\
Dapsone $(-)$ onset & $8(10.71)(0.69)$ & $12(9.29)(0.79)$ & 20 \\
Totals & 15 & 13 & 28 \\
\hline
\end{tabular}

The chi-square statistic is 5.1836. The $p$-value is 0.022801 . The result is considered significant at $p<0.05$. 


\subsection{Statistics 2: Fisher's Exact Test}

When using the chi-square test, there were cases where zero was entered into the cell, so this was replaced with 1. Fisher's test was conducted again to compensate for the Chi-squared test (Table 5).

Table 5. Fisher's exact test calculator.

\begin{tabular}{cccc}
\hline Study 2-4 & $\mathbf{d e c F I O}_{\mathbf{2}}+$ No Progressive & Progressive & Row Totals \\
\hline Dapsone (+) onset + aggravated & 17 & 3 & 20 \\
Dapsone $(+)$ severe & 0 & 2 & 2 \\
Total & 17 & 5 & 22 \\
\hline
\end{tabular}

Fisher's exact test statistic value is 0.0433 . The result is considered significant at $p<0.05$.

Both results for the dapsone trial group are significant for the ARDS onset stage and ARDS aggravated stage. Moreover, we examined the ARDS onset stage only. There were eight ARDS onset patients who received standard COVID-19 treatment with dapsone (a total of 22 patients). They did not die, except for one patient who did not take dapsone after relapse. Eight of twenty ARDS onset patients (a total of 22 patients) who received standard COVID-19 treatment without dapsone died.

\subsection{Statistics 3: Chi-Squared Test for ARDS Onset and Mortality}

The mortality rates at the ARDS onset stage were 0 and $40 \%$, respectively. The 17 participants at the ARDS onset stage who received the dapsone intervention $(\mathrm{M}=1.7$, $\mathrm{SD}=2.6268)$ compared to the 20 participants in the control group $(\mathrm{M}=2.8, \mathrm{SD}=3.7947)$ demonstrated a significantly lower mortality score. A chi-square test of independence was performed to examine the mortality relation between ARDS onset (with dapsone) and ARDS onset (without dapsone). The relation between these variables was significant: The chi-square statistic is 5.8108. The $p$-value is 0.015928 (significant at $p<0.05$ ). The ARDS onset (with dapsone) group was more likely to survive than the ARDS onset (without dapsone) group (Table 6).

Table 6. Chi-squared test for mortality.

\begin{tabular}{cccc}
\hline & Death & Survival & Row Totals \\
\hline ARDS onset (with dapsone) & 1 & 16 & 17 \\
\hline ARDS onset (without dapsone) & 8 & 12 & 20 \\
\hline Totals & 9 & 28 & 37 \\
\hline
\end{tabular}

Significance Level

Dapsone can be administered to all the ARDS onset patients. The involvement of the brainstem, especially the pre-Bötzinger complex, could explain the respiratory failure and high death rate of the COVID-19 ARDS patients and the sudden recovery of the ARDS onset patients after taking dapsone with standard COVID-19 treatment. It is recommended to use $200 \mathrm{mg}$ of dapsone as the standard dosage at the beginning of ARDS according to clinical experience. Furthermore, even after discharge, to suppress inflammasomes and prevent sequelae, 50-100 mg should be administered daily.

\section{Treatment Mechanisms}

The mode of dapsone-DNA interaction has been demonstrated using biophysical and in silico molecular docking techniques. Various research methods, such as ultravioletvisible and titrimetric fluorescence studies, circular dichroism, thermal denaturation and viscosity experiments, and competitive binding studies, have shown that dapsone noncovalently binds to the minor groove of DNA $[6,48]$. 
The molecular properties of dapsone have been elucidated at the chemical bonding, atomic, and molecular levels, including the electron density and Laplacian delocalization index $[49,50]$. The oxidation mechanism of dapsone is explained by electron transfer, and its redox properties are dependent on amine and sulfone moieties. The aniline ring has a nucleophilic moiety. It confers biological properties via a redox mechanism, mainly electron transfer or oxidation [51]. The topological properties of dapsone, such as its electron density and Laplacian delocalization index, reveal a very high positive Bader atomic charge (2.36e), as it is attached to the two most electronegative oxygen $(\mathrm{O})$ atoms $(-1.27 \mathrm{e})$ on both sides. The electron localization function has been used to visualize and deduce information on the lone pair and the subshells of the electrostatic potential regions susceptible to nucleophilic and electrophilic attack [49]. The negative potential of the vicinity of $\mathrm{O}$ and $\mathrm{O}$ atoms is vulnerable to severe electrophilic attack. The nucleophilic/electrophilic region of dapsone interacts with amino acids by molecular bonding. Dapsone has a structure that can reduce the production of the sulfur radical by electron charge transfer because it is structurally similar to methionine sulfoxide.

Dapsone has been noted in various diverse neuropathological findings, including those on its mysterious sensory manifestations observed via Heisenberg's uncertainty principle in quantum mechanics [52]. Dapsone has been used as a therapeutic agent for mild cognitive impairment [9,21], AD [14], PD [22,23], seizures [24], strokes [13,25,26], and, finally, COVID-19 ARDS [6].

When we detected the absorption wavelength values for the electronic spectra of dapsone, the protonated dapsone species were strongly dependent on $\mathrm{pH}$ through the excited states. Dapsone is a small molecule with anti-inflammatory and immunosuppressive properties as well as antibacterial and antibiotic properties. Dapsone passes through the BBB [53,54], and high-dose sulfadiazine results in an effective CSF concentration in humans [46].

Mechanism 1: Myeloperoxidase is an oxidoreductase that catalyzes the following chemical reaction: $\mathrm{H}_{2} \mathrm{O}_{2}+\mathrm{Cl}^{-}=\mathrm{H}_{2} \mathrm{O}+\mathrm{OCl}^{-}$. Dapsone binds to myeloperoxidase and regulates the production of hypochlorite. It reduces the inflammatory responses of cells.

Mechanism 2: The nucleophilic/electrophilic region of dapsone interacts with amino acids by molecular bonding. Neurotoxicity, aggregation, and free radical formation are initiated by the methionine (Met) residue at position 35 in the $C$-terminal domain of amyloid $\beta$ peptides $(\mathrm{A} \beta$ ) [55-57]. The two-electron oxidation of bicarbonate is mediated by hydrogen peroxide after the generation of peroxymonocarbonate $\left(\mathrm{HCO}^{-}\right)$. The bicarbonate/carbon dioxide pair stimulates one-electron oxidation. Carbonate radical anions $\left(\mathrm{CO}^{\bullet-}\right)$ mediate one-electron reactions to promote one-electron oxidation, efficiently oxidizing the thioether sulfur of the Met residue to sulfur radical cations $\left(\mathrm{MetS}^{\bullet+}\right)$ [58]. Dapsone has a structure that can reduce the production of the positively charged sulfur radical because it has a structure similar to that of methionine sulfoxide.

Mechanism 3: Due to its nucleophilic properties, dapsone competes with ubiquitin $(\mathrm{Ub})$. Before $\mathrm{Ub}$ is loaded onto the substrate, the $\mathrm{Ub}$-activating (E1)/Ub-conjugating (E2)/E3 ligase acts at each stage of the ubiquitination process, and the enzymes are all able to carry ubiquitin via a thioester linkage, which allows an energetically favorable attack of the substrate nucleophile. Dapsone can compete with the ubiquitination cascade. An identical mechanism can potentially ubiquitinate cysteine thiols and hydroxyls on serines, threonines, leucines, and tyrosines.

Mechanism 4: Dapsone noncovalently binds/interacts with the minor groove of DNA. The relative energy of the dapsone-DNA interaction/binding is $-6.22 \mathrm{kcal} \mathrm{mol}^{-1}$, as estimated by in silico studies. The docking analysis further revealed that dapsone preferentially binds to AT-rich regions of DNA [48]. The nucleophilic properties of dapsone mean that it competes with NLRP3. ORF8b activates NLRP3 through direct interaction with the AT-rich repeat domain of NLRP3 [6].

Dapsone has been used to improve the efficiency of newly developed drugs in treating significant diseases. 


\section{Investigation of SARS-CoV-2 Vaccination and Nanobody Drugs}

Messenger RNA (mRNA) is a crucial molecule of life in almost all aspects of cell biology, and synthetic mRNA has been engineered to resemble mature and processed mRNA molecules in the cytoplasm of eukaryotic cells [59]. A lipoplex (LPX) protects RNA from extracellular ribonucleases by optimally adjusting the net charge. We can intravenously administer RNA-lipoplexes (RNA-LPXs) as well-known lipid carriers for the systemic delivery of vaccine antigens. In a study, RNA-LPXs encoding viral or mutant neo-antigens or endogenous self-antigens induced potent effector and memory T-cell responses; consequently, IFN $\alpha$ and robust antigen-specific T-cell responses were induced in the first three melanoma patients [60]. An RNA-LPX that encoded the receptor-binding domain (RBD) of the SARS-CoV-2 spike protein was constructed [61], and RBD-binding IgG concentrations and SARS-CoV-2-neutralizing titers in the sera were increased with the dose and after a second dose [61]. A two-dose-regimen vaccine conferred 95\% protection against COVID-19 in younger and older persons [62]. However, clinical observations indicate a potential risk of illness after successful vaccination and subsequent infection with the variant virus [63].

Researchers identified nanobodies that specifically bind to the RBD of the virus with an equilibrium dissociation constant between 2 and $22 \mathrm{nmol}$ and neutralized SARS-CoV-2 infection by $50 \%$ in a plaque reduction assay at concentrations ranging from 48 to $185 \mathrm{nmol}$; the results are similar to those achieved with monoclonal antibodies [64]. Nanobodies can be made with the use of prokaryotic expression systems that are easier to manufacture than standard monoclonal antibodies.

Lipid nanoparticles and nanobodies are under clinical investigation for treating various diseases, from cancer to infectious diseases. We highly desire therapies that are safe and effective against variants and offer an alternative to intravenously administered antibody drugs.

The use of oral therapeutics that modulate inflammasomes without compromising the adaptive immune response are likely to be the most effective therapeutic strategy. Here, we suggest that the dapsone-DNA complex can be used as an oral therapeutic for SARS-CoV-2 ARDS. Unlike RNA-RPXs, dapsone does not bind to the RBD but formulates the dapsone-DNA complex, which prevents the exacerbation of SARS-CoV-2 inflammasomes in the brain. Moreover, when RBCs split in the blood microcirculation, they release iron-rich, strongly magnetic nanoparticles associated with diverse SARS-CoV-2 pathology in mitochondria, the endoplasmic reticulum, and the sites of near-contact between the mitochondrion and the endoplasmic reticulum (ER) (mitochondrion-ER), axons, and dendrites [65].

Dapsone inhibits myeloperoxidase (MPO), and the peroxidase activity of heme-bound $\mathrm{A} \beta$ is associated with $\mathrm{AD}[66]$. $\mathrm{A} \beta$ plays a key role by oxidatively impairing the capacity of red blood cells (RBCs) to deliver oxygen to the brain, and RBC deformability leads to abnormalities in the blood microcirculation [67]. Native MPO is a homodimer with two identical monomeric MPOs connected by a single disulfide bond [68], but hemi-MPO resulting from disulfide cleavage can be produced. Two types of MPO bind to the RBCs plasma membranes, which leads to reduced cell resistance to osmotic and acidic hemolysis, a reduction in cell elasticity, and significant changes in cell volume, morphology, and the conductance of ion channels in the RBC's plasma membrane. MPO, an oxidant-producing enzyme, was shown to cause RBC deformability, leading to abnormalities in the blood microcirculation [69]. Dapsone is a well-known MPO inhibitor [9] that protects neurons from SARS-CoV-2 inflammasomes through RBC splitting and ameliorates SARS-CoV-2 ARDS [27]. Dapsone acts as a competitor of canonical/noncanonical ubiquitylation, NLRP3 inflammasome formation, Higgins' cascade, and strongly magnetic iron-rich nanoparticles.

Proteins covalently attached to DNA are common and impose physical obstacles to DNA replication, repair, transcription, and recombination [70]. Large DNA-protein crosslinks can be cleaved into DNA-peptide crosslinks, but these smaller fragments also disrupt normal replication [71]. 
The dapsone-DNA complex may disrupt DNA replication, repair, transcription, and recombination of SARS-CoV-2 inflammasomes based on the fact that it has previously been used as an adjuvant [15], alternative [16], augmentation [17,18], or active ingredient [21,22] by clinicians. Dapsone has been used as a therapeutic agent for mild cognitive impairment [9,21], AD [14], PD [22,23], seizures [24], strokes [13,25,26], and, finally, COVID-19 ARDS [6,27] before dapsone was identified as an inflammasome competitor. This indicates that dapsone can be used along with an oral DNA vaccine for physically obstructing the replication of DNA in inflammasomes.

Recently, incident sequelae have been identified in the respiratory system and several others, including the nervous system, leading to neurocognitive disorders, mental health disorders, metabolic disorders, cardiovascular disorders, gastrointestinal disorders, malaise, fatigue, musculoskeletal pain, and anemia, with the increased incident use of several therapeutics, including pain medications, antidepressants, anxiolytics, antihypertensives, and oral hypoglycemics, and evidence of laboratory abnormalities for multiple organ systems [72]. This also indicates that dapsone can be used to treat sequelae, by the mechanism of physical obstacles to the replication of DNA in inflammasomes exacerbating states, if the doctor prescribes dapsone and monitors its side effects to treat the disease

\section{Conclusions and Future Directions}

Given the existing knowledge of SARS-CoV-2 inflammasomes and sequelae, the wide range of symptoms associated with COVID-19 is not surprising, and sequelae are also likely to be increasingly observed in SARS-CoV-2 survivors. We need to go beyond the traditional vaccine concept and quickly introduce ad hoc prevention and treatment methods. Dapsone is a drug with side effects; however, these are manageable, and, thus, its use is worth exploring.

If doctors prescribe dapsone to patients in the ARDS onset stage, those with COVID-19 may have a higher chance of survival.

Supplementary Materials: The following are available online at https://www.mdpi.com/article/10 $.3390 /$ vaccines $9060635 / \mathrm{s} 1$.

Author Contributions: J.-H.L. devised the idea for this rapid review. B.K. and C.J.L. reviewed the manuscript. B.K. conducted the clinical study. C.J.L. analyzed the statistical studies. J.-H.L. wrote the manuscript. All authors have read and agreed to the published version of the manuscript.

Funding: This research received no external funding.

Institutional Review Board Statement: Not applicable.

Informed Consent Statement: Not applicable.

Data Availability Statement: Data sharing not applicable.

Conflicts of Interest: All authors declare no competing interests.

\section{References}

1. Riley, S.; Ainslie, K.E.C.; Eales, O.; Walters, C.E.; Wang, H.; Atchison, C.; Fronterre, C.; Diggle, P.J.; Ashby, D.; Donnelly, C.A.; et al. Resurgence of SARS-CoV-2: Detection by community viral surveillance. Science 2021, 372, 990-995. [CrossRef]

2. Johns Hopkins University, C.R.C. Coronavirus Resource Center. Available online: https://coronavirus.jhu.edu/ (accessed on 24 April 2021).

3. Cabinet Office. Coronavirus (COVID-19): What Has Changed-9 September. Available online: https://www.gov.uk/ government/news/coronavirus-covid-19-what-has-changed-9-september (accessed on 24 April 2021).

4. Ellul, M.A.; Benjamin, L.; Singh, B.; Lant, S.; Michael, B.D.; Easton, A.; Kneen, R.; Defres, S.; Sejvar, J.; Solomon, T. Neurological associations of COVID-19. Lancet Neurol. 2020, 19, 767-783. [CrossRef]

5. Meinhardt, J.; Radke, J.; Dittmayer, C.; Franz, J.; Thomas, C.; Mothes, R.; Laue, M.; Schneider, J.; Brünink, S.; Greuel, S.; et al. Olfactory transmucosal SARS-CoV-2 invasion as a port of central nervous system entry in individuals with COVID-19. Nat. Neurosci. 2021, 24, 168-175. [CrossRef]

6. Lee, J.-H.; An, H.K.; Sohn, M.-G.; Kivela, P.; Oh, S. 4,4'-Diaminodiphenyl Sulfone (DDS) as an Inflammasome Competitor. Int. J. Mol. Sci. 2020, 21, 5953. [CrossRef] 
7. Lee, M.-H.; Perl, D.P.; Nair, G.; Li, W.; Maric, D.; Murray, H.; Dodd, S.J.; Koretsky, A.P.; Watts, J.A.; Cheung, V.; et al. Microvascular injury in the brains of patients with COVID-19. N. Engl. J. Med. 2020, 384, 481-483. [CrossRef]

8. Yachou, Y.; El Idrissi, A.; Belapasov, V.; Ait Benali, S. Neuroinvasion, neurotropic, and neuroinflammatory events of SARS-CoV-2: Understanding the neurological manifestations in COVID-19 patients. Neurol. Sci. 2020, 41, 2657-2669. [CrossRef] [PubMed]

9. Lee, J.H.; Choi, S.H.; Lee, C.J.; Oh, S.S. Recovery of Dementia Syndrome following Treatment of Brain Inflammation. Dement. Geriatr. Cogn. Disord. Extra 2020, 10, 1-12. [CrossRef] [PubMed]

10. Namba, Y.; Kawatsu, K.; Izumi, S.; Ueki, A.; Ikeda, K. Neurofibrillary tangles and senile plaques in brain of elderly leprosy patients. Lancet 1992, 340, 978. [CrossRef]

11. Kimura, T.; Goto, M. Existence of senile plaques in the brains of elderly leprosy patients. Lancet 1993, 342, 1364. [CrossRef]

12. Endoh, M.; Kunishita, T.; Tabira, T. No effect of anti-leprosy drugs in the prevention of Alzheimer's disease and $\beta$-amyloid neurotoxicity. J. Neurol. Sci. 1999, 165, 28-30. [CrossRef]

13. Lee, J.-H.; Lee, C.J.; Park, J.; Lee, S.J.; Su-Hee, C. The neuro-inflammasome in Alzheimer's disease and cerebral stroke. Dement. Geriatr. Cogn. Disord. Extra 2021. [CrossRef]

14. Jong-Hoon, L.; Chul Joong, L.; Jungwuk, P.; So Jeong, L.; Su-Hee, C.; Sang-Suk, O. The Preventive and Treatment of the Neuroinflammasome in Sorokdo National Hospital. Res. Sq. 2021. [CrossRef]

15. Tirado-Sánchez, A.; Díaz-Molina, V.; Ponce-Olivera, R. Efficacy and safety of azathioprine and dapsone as an adjuvant in the treatment of bullous pemphigoid. Allergol. Immunopathol. 2012, 40, 152-155. [CrossRef]

16. Salehzadeh, F.; Jahangiri, S.; Mohammadi, E. Dapsone as an alternative therapy in children with familial Mediterranean fever. Iran. J. Pediatr. 2012, 22, 23. [PubMed]

17. Tamarkin, D.; Friedman, D.; Eini, M. Anti-Infection Augmentation Foamable Compositions and Kit and Uses Thereof. U.S. Patent Application US11/732,547, 20 December 2007.

18. Kast, R.E. Erlotinib augmentation with dapsone for rash mitigation and increased anti-cancer effectiveness. SpringerPlus 2015, 4, 638. [CrossRef]

19. Park, S.C.; Lee, J.; Cho, S.C.; Park, M.C.; Cho, Y.J. Composition for Control of Aging and/or Extension of Life, Containing Dapsone as Active Ingredient. U.S. Patent Application US12/737,553, 23 June 2011.

20. McGeer, P.L.; Harada, N.; Kimura, H.; McGeer, E.G.; Schulzer, M. Dapsone and Promin for the Treatment of Dementia. U.S. Patent Application US5532219A, 2 July 1996.

21. Yang, N.; Li, L.; Li, Z.; Ni, C.; Cao, Y.; Liu, T.; Tian, M.; Chui, D.; Guo, X. Protective effect of dapsone on cognitive impairment induced by propofol involves hippocampal autophagy. Neurosci. Lett. 2017, 649, 85-92. [CrossRef]

22. Sulzer, D.; Antonini, A.; Leta, V.; Nordvig, A.; Smeyne, R.J.; Goldman, J.E.; Al-Dalahmah, O.; Zecca, L.; Sette, A.; Bubacco, L.; et al. COVID-19 and possible links with Parkinson's disease and parkinsonism: From bench to bedside. NPJ Parkinson's Dis. 2020, 6, 1-10. [CrossRef] [PubMed]

23. Zhao, K.; Lim, Y.J.; Liu, Z.; Long, H.; Sun, Y.; Hu, J.J.; Zhao, C.; Tao, Y.; Zhang, X.; Li, D.; et al. Parkinson's disease-related phosphorylation at Tyr39 rearranges alpha-synuclein amyloid fibril structure revealed by cryo-EM. Proc. Natl. Acad. Sci. USA 2020, 117, 20305-20315. [CrossRef] [PubMed]

24. Kast, R.E.; Lefranc, F.; Karpel-Massler, G.; Halatsch, M.E. Why dapsone stops seizures and may stop neutrophils' delivery of VEGF to glioblastoma. Br. J. Neurosurg. 2012, 26, 813-817. [CrossRef]

25. Nader-Kawachi, J.; Góngora-Rivera, F.; Santos-Zambrano, J.; Calzada, P.; Ríos, C. Neuroprotective effect of dapsone in patients with acute ischemic stroke: A pilot study. Neurol. Res. 2007, 29, 331-334. [CrossRef]

26. Cruz-Cruz, C.; Kravzov-Jinich, J.; Martínez-Núñez, J.M.; Ríos-Castañeda, C.; Perez, M.E.; Altagracia-Martínez, M. Cost-utility analysis in acute ischemic stroke survivors treated with dapsone in a public hospital in Mexico City. J. Pharm. Health Serv. Res. 2014, 5, 95-102. [CrossRef]

27. Jong-Hoon, L.; Badar, K.; Chul Joong, L.; Asif, K.; Jenny, B.; Richard, E.K.; Sang-Suk, O.; Consolato, S. Randomized Controlled Trial of Dapsone for Targeting SARS-CoV-2-Activated Inflammasomes. Res. Sq. 2021. [CrossRef]

28. Singhal, T. A Review of Coronavirus Disease-2019 (COVID-19). Indian J. Pediatr. 2020, 87, 281-286. [CrossRef] [PubMed]

29. Zhang, F.R.; Liu, H.; Irwanto, A.; Fu, X.A.; Li, Y.; Yu, G.Q.; Yu, Y.X.; Chen, M.F.; Low, H.Q.; Li, J.H.; et al. HLA-B*13:01 and the Dapsone Hypersensitivity Syndrome. N. Engl. J. Med. 2013, 369, 1620-1628. [CrossRef]

30. Tian, S.; Hu, W.; Niu, L.; Liu, H.; Xu, H.; Xiao, S.-Y. Pulmonary pathology of early phase 2019 novel coronavirus (COVID-19) pneumonia in two patients with lung cancer. J. Thorac. Oncol. 2020, 15, 700-704. [CrossRef] [PubMed]

31. Frater, J.L.; Zini, G.; D'Onofrio, G.; Rogers, H.J. COVID-19 and the clinical hematology laboratory. Int. J. Lab. Hematol. 2020, 42, 11-18. [CrossRef]

32. Schmitt, J.; Lorenz, M.; Wozel, G. Hypersensitivity Reactions to Dapsone: A Systematic Review. Acta Derm. Venereol. 2012, 92, 194-199. [CrossRef]

33. Alves-Rodrigues, E.N.; Ribeiro, L.C.; Silva, M.D.; Takiuchi, A.; Fontes, C.J.F. Dapsone syndrome with acute renal failure during leprosy treatment: Case report. Braz. J. Infect. Dis. 2005, 9, 84-86. [CrossRef]

34. Wozel, V.G. Innovative use of dapsone. Dermatol. Clin. 2010, 28, 599-610. [CrossRef]

35. Bangash, M.N.; Patel, J.; Parekh, D. COVID-19 and the liver: Little cause for concern. Lancet Gastroenterol. Hepatol. 2020, 5, 529-530. [CrossRef] 
36. Liu, F.; Long, X.; Zou, W.; Fang, M.; Wu, W.; Li, W.; Zhang, B.; Zhang, W.; Chen, X.; Zhang, Z. Highly ACE2 Expression in Pancreas May Cause Pancreas Damage After SARS-CoV-2 Infection. medRxiv 2020. [CrossRef]

37. Zhu, K.; He, F.; Jin, N.; Lou, J.; Cheng, H. Complete atrioventricular block associated with dapsone therapy: A rare complication of dapsone-induced hypersensitivity syndrome. J. Clin. Pharm. Ther. 2009, 34, 489-492. [CrossRef]

38. Ghishan, F.K. The sulfone syndrome complicated by pancreatitis and pleural effusion in an adolescent receiving dapsone for treatment of acne vulgaris. J. Pediatr. Gastroenterol. Nutr. 1998, 26, 103-105.

39. Kissling, S.; Rotman, S.; Gerber, C.; Halfon, M.; Lamoth, F.; Comte, D.; Lhopitallier, L.; Sadallah, S.; Fakhouri, F. Collapsing glomerulopathy in a COVID-19 patient. Kidney Int. 2020, 98, 228-231. [CrossRef]

40. Zheng, Y.-Y.; Ma, Y.-T.; Zhang, J.-Y.; Xie, X. COVID-19 and the cardiovascular system. Nat. Rev. Cardiol. 2020, 17, 259-260. [CrossRef]

41. Kang, K.S.; Kim, H.I.; Kim, O.H.; Cha, K.C.; Kim, H.; Lee, K.H.; Hwang, S.O.; Cha, Y.S. Clinical outcomes of adverse cardiovascular events in patients with acute dapsone poisoning. Clin. Exp. Emerg. Med. 2016, 3, 41. [CrossRef] [PubMed]

42. Oxley, T.J.; Mocco, J.; Majidi, S.; Kellner, C.P.; Shoirah, H.; Singh, I.P.; De Leacy, R.A.; Shigematsu, T.; Ladner, T.R.; Yaeger, K.A.; et al. Large-Vessel Stroke as a Presenting Feature of COVID-19 in the Young. N. Engl. J. Med. 2020, 382, e60. [CrossRef] [PubMed]

43. Helms, J.; Kremer, S.; Merdji, H.; Clere-Jehl, R.; Schenck, M.; Kummerlen, C.; Collange, O.; Boulay, C.; Fafi-Kremer, S.; Ohana, M.; et al. Neurologic Features in Severe SARS-CoV-2 Infection. N. Engl. J. Med. 2020, 382, 2268-2270. [CrossRef]

44. Kast, R.E. Dapsone as treatment adjunct in ARDS. Exp. Lung Res. 2020, 46, 157-161. [CrossRef]

45. Miller, D.S. Regulation of P-glycoprotein and other ABC drug transporters at the blood-brain barrier. Trends Pharmacol Sci. 2010, 31, 246-254. [CrossRef]

46. Nau, R.; Sorgel, F.; Eiffert, H. Penetration of drugs through the blood-cerebrospinal fluid/blood-brain barrier for treatment of central nervous system infections. Clin. Microbiol. Rev. 2010, 23, 858-883. [CrossRef]

47. Kanwar, B.; Sergi, C.; Lee, J.-H. Hunt Regional Medical Center Policy for Dapsone Administration of ARDS by SARS-CoV-2; Kanwar, B., Ed.; OSF (Open Science Foundation): Charlotteville, VA, USA, 2020. [CrossRef]

48. Chakraborty, A.; Panda, A.K.; Ghosh, R.; Biswas, A. DNA minor groove binding of a well known anti-mycobacterial drug dapsone: A spectroscopic, viscometric and molecular docking study. Arch. Biochem. Biophys. 2019, 665, 107-113. [CrossRef]

49. Rajendran, N.D.; Mookan, N.; Samuel, I.; Mookan, S.B.; Munusamy, G.; Gurudeeban, S.; Kaliamurthi, S. A theoretical study of chemical bonding and topological and electrostatic properties of the anti-leprosy drug dapsone. J. Mol. Model. 2020, 26, 138. [CrossRef] [PubMed]

50. Kim, S.-K.; Lee, S.-B.; Kang, T.-J.; Chae, G.-T. Detection of gene mutations related with drug resistance inMycobacterium lepraefrom leprosy patients using Touch-Down (TD) PCR. FEMS Immunol. Med. Microbiol. 2003, 36, 27-32. [CrossRef]

51. Mendes, A.P.; Schalcher, T.R.; Barros, T.G.; Almeida, E.D.; Maia, C.S.; Barros, C.A.; Monteiro, M.C.; Borges, R.S. A Geometric and Electronic Study of Dapsone. J. Comput. Theor. Nanosci. 2011, 8, 1428-1431. [CrossRef]

52. Schrodinger, R.; Schrödinger, E. What Is life? With Mind and Matter and Autobiographical Sketches; Cambridge University Press: Cambridge, UK, 1992.

53. Gatti, G.; Hossein, J.; Malena, M.; Cruciani, M.; Bassetti, M. Penetration of dapsone into cerebrospinal fluid of patients with AIDS. J. Antimicrob. Chemother. 1997, 40, 113-115. [CrossRef] [PubMed]

54. Rich, J.D.; Mirochnick, M. Dapsone penetrates cerebrospinal fluid during Pneumocystis carinii pneumonia prophylaxis. Diagn. Microbiol. Infect. Dis. 1996, 24, 77-79. [CrossRef]

55. Varadarajan, S.; Yatin, S.; Kanski, J.; Jahanshahi, F.; Butterfield, D.A. Methionine residue 35 is important in amyloid $\beta$-peptideassociated free radical oxidative stress. Brain Res. Bull. 1999, 50, 133-141. [CrossRef]

56. Vogt, W. Oxidation of methionyl residues in proteins: Tools, targets, and reversal. Free Radic. Biol. Med. 1995, 18, 93-105. [CrossRef]

57. Enache, T.A.; Oliveira-Brett, A.M. Alzheimer's disease amyloid beta peptides in vitro electrochemical oxidation. Bioelectrochemistry 2017, 114, 13-23. [CrossRef]

58. Francioso, A.; Baseggio Conrado, A.; Blarzino, C.; Foppoli, C.; Montanari, E.; Dinarelli, S.; Giorgi, A.; Mosca, L.; Fontana, M. Oneand Two-Electron Oxidations of beta-Amyloid25-35 by Carbonate Radical Anion (CO3 $\left.\left({ }^{*}-\right)\right)$ and Peroxymonocarbonate (HCO4(-)): Role of Sulfur in Radical Reactions and Peptide Aggregation. Molecules 2020, 25, 961. [CrossRef]

59. Sahin, U.; Karikó, K.; Türeci, Ö. mRNA-based therapeutics-Developing a new class of drugs. Nat. Rev. Drug Discov. 2014, 13, 759-780. [CrossRef]

60. Kranz, L.M.; Diken, M.; Haas, H.; Kreiter, S.; Loquai, C.; Reuter, K.C.; Meng, M.; Fritz, D.; Vascotto, F.; Hefesha, H.; et al. Systemic RNA delivery to dendritic cells exploits antiviral defence for cancer immunotherapy. Nature 2016, 534, 396-401. [CrossRef] [PubMed]

61. Mulligan, M.J.; Lyke, K.E.; Kitchin, N.; Absalon, J.; Gurtman, A.; Lockhart, S.; Neuzil, K.; Raabe, V.; Bailey, R.; Swanson, K.A.; et al. Phase I/II study of COVID-19 RNA vaccine BNT162b1 in adults. Nature 2020, 586, 589-593. [CrossRef] [PubMed]

62. Walsh, E.E.; Frenck, R.W.; Falsey, A.R.; Kitchin, N.; Absalon, J.; Gurtman, A.; Lockhart, S.; Neuzil, K.; Mulligan, M.J.; Bailey, R.; et al. Safety and Immunogenicity of Two RNA-Based Covid-19 Vaccine Candidates. N. Engl. J. Med. 2020, 383, $2439-2450$. [CrossRef] 
63. Hacisuleyman, E.; Hale, C.; Saito, Y.; Blachere, N.E.; Bergh, M.; Conlon, E.G.; Schaefer-Babajew, D.J.; Dasilva, J.; Muecksch, F.; Gaebler, C.; et al. Vaccine Breakthrough Infections with SARS-CoV-2 Variants. N. Engl. J. Med. 2021. Online ahead of print. [CrossRef] [PubMed]

64. Xiang, Y.; Nambulli, S.; Xiao, Z.; Liu, H.; Sang, Z.; Duprex, W.P.; Schneidman-Duhovny, D.; Zhang, C.; Shi, Y. Versatile and multivalent nanobodies efficiently neutralize SARS-CoV-2. Science 2020, 370, 1479-1484. [CrossRef]

65. Calderón-Garcidueñas, L.; González-Maciel, A.; Reynoso-Robles, R.; Kulesza, R.J.; Mukherjee, P.S.; Torres-Jardón, R.; Rönkkö, T.; Doty, R.L. Alzheimer's disease and alpha-synuclein pathology in the olfactory bulbs of infants, children, teens and adults $\leq 40$ years in Metropolitan Mexico City. APOE4 carriers at higher risk of suicide accelerate their olfactory bulb pathology. Environ. Res. 2018, 166, 348-362. [CrossRef] [PubMed]

66. Roy, M.; Pal, I.; Nath, A.K.; Dey, S.G. Peroxidase activity of heme bound amyloid $\beta$ peptides associated with Alzheimer's disease. Chem. Commun. 2020, 56, 4505-4518. [CrossRef]

67. Kiko, T.; Nakagawa, K.; Satoh, A.; Tsuduki, T.; Furukawa, K.; Arai, H.; Miyazawa, T. Amyloid $\beta$ levels in human red blood cells. PLoS ONE 2012, 7, e49620. [CrossRef]

68. Blair-Johnson, M.; Fiedler, T.; Fenna, R. Human myeloperoxidase: Structure of a cyanide complex and its interaction with bromide and thiocyanate substrates at $1.9 \AA$ resolution. Biochemistry 2001, 40, 13990-13997. [CrossRef] [PubMed]

69. Shamova, E.V.; Gorudko, I.V.; Grigorieva, D.V.; Sokolov, A.V.; Kokhan, A.U.; Melnikova, G.B.; Yafremau, N.A.; Gusev, S.A.; Sveshnikova, A.N.; Vasilyev, V.B. The effect of myeloperoxidase isoforms on biophysical properties of red blood cells. Mol. Cell. Biochem. 2020, 464, 119-130. [CrossRef] [PubMed]

70. Ruggiano, A.; Ramadan, K. DNA-protein crosslink proteases in genome stability. Commun. Biol. 2021, 4, 11. [CrossRef] [PubMed]

71. Ghodke, P.P.; Gonzalez-Vasquez, G.; Wang, H.; Johnson, K.M.; Sedgeman, C.A.; Guengerich, F.P. Enzymatic bypass of an N6-deoxyadenosine DNA-ethylene dibromide-peptide cross-link by translesion DNA polymerases. J. Biol. Chem. 2021, 296, 100444. [CrossRef]

72. Al-Aly, Z.; Xie, Y.; Bowe, B. High-dimensional characterization of post-acute sequalae of COVID-19. Nature 2021. Online ahead of print. [CrossRef] [PubMed] 